\title{
1. Governing for the Future while Meeting the Challenges of Today
}

\author{
Jonathan Boston
}

The world we have made, as a result of the level of thinking we have done thus far, creates problems we cannot solve at the same level of thinking at which we created them. (Albert Einstein, quoted in MacHale 2002)

Powerful global forces will reshape the context ... over the next few decades. They include increasing international connectedness, geopolitical power shifts, rapid technological developments, demographic changes, climate change, growing resource scarcity and changing values ... Together they are creating a world that is fast-paced, heterogeneous, complex and unpredictable. (Gill et al. 2011:29)

\section{The Nature of the Problem}

We live in the midst of significant social, demographic, economic, technological and environmental changes and challenges. In tackling these, governments need to focus simultaneously on issues of immediate, practical concern and those of a longer-term, more enduring or fundamental nature. Moreover, in responding to the pressing problems of today, policymakers and public managers must keep a watchful eye on the issues of tomorrow, including how the short-term policy 'solutions' they adopt will affect future risks, challenges, opportunities and capabilities. Put briefly, this means governing for the future. Governments must take a long-term view - looking out over decades, if not centuries, not merely a single electoral cycle of three or four years.

A crucial goal of such an approach is future-proofing the state-that is, anticipating and preparing for foreseeable challenges, managing and mitigating risks, building resilience and reducing future vulnerabilities, thereby ensuring a better, more sustainable tomorrow. These tasks, of course, are complex and hard - conceptually, analytically and, above all, politically. A range of possible futures needs to be imagined. Potential risks need to be identified and assessed. Judgments must be made about what level of risk is socially acceptable. Difficult policy trade-offs must be confronted. Intergenerational costs and benefits must be calculated. Ethically justifiable discount rates must be applied. And in the 
midst of all this, governments need to be constantly mindful of the likelihood of surprises, including rare, unpredictable, high-impact events - what are now referred to as 'black swan events', as discussed by Peter Ho in Chapter 5.

To undertake all these tasks competently requires astute leadership, foresight and wisdom. It also depends on robust evidence and excellent science. Some of these ingredients are often in short supply. Yet frequent calls are made for 'better future-proofing' as governments attempt to manage in the aftermath of crises and disasters; this applies not only to natural disasters such as earthquakes, floods and fires, but also to financial crises, pandemics, technological failures, moral panics and the unintended, damaging consequences of the state's own actions. So how can we improve the future-proofing of the state?

The 2012 Australia and New Zealand School of Government (ANZSOG) Annual Conference held in Wellington, New Zealand, brought together leading thinkers and expert practitioners to consider various dimensions of future-proofing, including the following.

1. What does the future hold, and can we predict and manage it better? What long-term challenges are likely to confront our political systems and how can we identify them and prepare for them sooner rather than later?

2. Can we realign or transform our political context - which is dominated by the tyranny of the urgent, short-term policy imperatives and the pervasive effects of the electoral cycle - to ensure that long-term problems and risks receive adequate attention and thereby prepare ourselves to meet future challenges? And what institutional mechanisms might be available to increase the incentives for policymakers to take long-term issues more seriously?

3. What can we learn as policymakers and public managers from our region's recent experiences in recovering from major natural disasters? Such learning may involve rethinking our practices of public management (including the processes of inter-agency collaboration), getting better at anticipating, managing and sharing risk (at individual, local community, national and international levels), and using recovery strategies to enable communities to withstand better the turbulent times that lie ahead.

4. How do we (re)build trust and foster resilience, which holds our nations and communities together, in the face of significant challenges, such as natural disasters?

The decision to focus on future-proofing our modes of governance reflected the fact that governments and communities will confront many significant challenges and risks over the coming decades - be they economic, social, political, environmental, technological, geological or meteorological (see Howell 2013). There is thus a need for appropriate foresight, planning and 
preparedness. Serious risks that threaten public health and safety or the capacity of governments to maintain public order must be properly identified and mitigated (at least to the extent that this is feasible and cost-effective); and governments need to develop the capability and tools to address such challenges as and when they arise.

For those immersed in emergency management, such tasks are part and parcel of the job. The relevant policy frameworks and language may differ somewhat between countries, but the basic roles and demands are similar. For instance, in New Zealand, emergency management focuses on the so-called four 'rs' relating to disasters: reduction, readiness, response and recovery. The Australian equivalents are prevention, preparedness, response and recovery. Of course, whatever the precise labels, the basic objectives are closely related and interconnected. Thus, for instance, any sensible recovery effort in the wake of a major disaster needs to give appropriate attention to prevention and preparedness - that is, for the next disaster. Moreover, the recovery process is not merely about the reconstruction of physical infrastructure, but it is also-more fundamentally - about the restoration of the afflicted communities (assuming this is feasible and sensible). It is thus concerned with all aspects of human wellbeing - social, economic, environmental, psychological and physical.

Yet future-proofing the state goes well beyond emergency management, as is highlighted by many of the contributions to this volume. It is not simply about preparing for, or responding to, disasters of one kind or another. The challenge is far broader. Indeed, so large is the potential canvas, so demanding the task, it might reasonably be asked whether future-proofing the state is a meaningful, realistic or sensible objective. After all, future-proofing may simply be too difficult. For instance, the future may be considered too unpredictable and uncertain, and/or the potential risks too severe, and/or the complexity and gravity of the challenges too great and/or the policy tools, resources and capacities of governments too limited. Yet while such impediments might render the goal of future-proofing immensely demanding, and while complete futureproofing is certainly a forlorn hope, this does not mean that no effort should be made. There is no case for giving up in despair. Realistically, we cannot turn our back to the future; nor would it be ethically justified to turn a blind eye in the face of well-established and serious risks. Individually and collectively we have a moral responsibility to take seriously the challenges that confront us on the horizon and prepare as best we can for whatever the future may hold. Equally, we owe it to future generations to consider carefully how our actions today will impact on their wellbeing - and, wherever possible, minimise the potential harms and maximise the projected benefits.

In all such matters it will be essential for governments to take the lead. Only the state has the means to undertake the necessary horizon scanning, risk 
identification and assessments, and the required strategising and planning. Only the state has the coordinating capacity, legitimacy and coercive powers to determine the appropriate actions, channel the required resources and incentivise the desired behaviours. Unavoidably, therefore, citizens look to their governments for leadership - to understand what is going on, to prepare and plan, to mitigate risks and to respond when crises occur. Inevitably, too, citizens are quick to blame governments that fail to exercise proper foresight or tolerate unacceptable levels of risk. This immediately raises several difficulties. What constitutes an acceptable level of risk varies over time. Citizens tend to be much more risk-averse immediately after a disaster or crisis than before such events.

Equally important, the incentives in democratic political systems are for decision-makers to focus on contemporary ills rather than future threats and opportunities. Likewise, there are short-term electoral incentives for politicians to engage in 'bias arbitrage' - that is, to focus on issues for which the public exaggerates the risks and to downplay or ignore those issues for which the public underestimates the risks (for example, climate change). This structuring of political incentives generates a constant and enduring challenge to ensure that the state invests adequately in the task of governing for the future and protecting humanity's long-term interests. Fundamentally, of course, this is a governance issue: it is about the quality of leadership; it is about resource allocation and priority setting; and it is about ensuring that narrow, short-term considerations and powerful vested interests do not override the wider public interest.

With these broad considerations in mind, this chapter has three main purposes. First, it identifies the major long-term challenges and risks facing humanity, including some of those specific to the Australasian and South Pacific regions. Second, it briefly examines the respective roles of governments and other stakeholders in preparing to meet these challenges and risks. Third, it explores what is meant by 'future-proofing the state' and discusses some of the specific issues raised by this task. These include, among other things, how to increase the incentives for governments to give proper weight to long-term policy issues; how governments might enhance the resilience of public institutions and critical subsystems and hence improve their capacity to cope with shocks; and how, in responding to various stresses and crises, it might be possible to maintain, if not enhance, public trust in governmental institutions. Where appropriate, I will refer briefly to other contributions to this volume. 


\section{The Challenges Facing Humanity}

What are the critical long-term challenges, risks and potential shocks that humanity faces? Plainly, there are many: some we know about or can be readily foreseen; others are as yet unknown (see Howell 2013; Lee et al. 2012; Smil 2006; Upton 2012; and Chapter 3, this volume). Those we know about differ significantly in their nature, complexity, probable impact and likely duration. They can also be grouped in many different ways. For instance, a risk analysis prepared for the 2013 World Economic Forum (Howell 2013) classifies the most important current global risks under five general headings: economic, environmental, geopolitical, societal and technological. Ten specific risks are then identified and assessed under each heading, giving 50 risks in all. These are set out in Table 1.1.

Table 1.1 Global Risk Landscape by Categories

\begin{tabular}{|c|c|c|c|}
\hline $\begin{array}{l}\text { General } \\
\text { category }\end{array}$ & & Type of risk & Description \\
\hline \multirow[t]{10}{*}{ Economic } & 1 & $\begin{array}{l}\text { Chronic fiscal } \\
\text { imbalances }\end{array}$ & $\begin{array}{l}\text { Failure to redress excessive government debt } \\
\text { obligations }\end{array}$ \\
\hline & 2 & $\begin{array}{l}\text { Chronic labour } \\
\text { market imbalances }\end{array}$ & $\begin{array}{l}\text { A sustained high level of underemployment } \\
\text { and unemployment that is structural rather } \\
\text { than cyclical in nature }\end{array}$ \\
\hline & 3 & $\begin{array}{l}\text { Extreme volatility } \\
\text { in energy and } \\
\text { agricultural prices }\end{array}$ & $\begin{array}{l}\text { Severe price fluctuations make critical } \\
\text { commodities unaffordable, slow growth, } \\
\text { provoke public protest and increase geopolitical } \\
\text { tension }\end{array}$ \\
\hline & 4 & $\begin{array}{l}\text { Hard landing of } \\
\text { emerging economies }\end{array}$ & $\begin{array}{l}\text { The abrupt slowing of a critical emerging } \\
\text { economy }\end{array}$ \\
\hline & 5 & $\begin{array}{l}\text { Major systemic } \\
\text { financial failure }\end{array}$ & $\begin{array}{l}\text { A financial institution or currency regime } \\
\text { of systematic importance collapses with } \\
\text { implications throughout the global financial } \\
\text { system }\end{array}$ \\
\hline & 6 & $\begin{array}{l}\text { Prolonged } \\
\text { infrastructure } \\
\text { neglect }\end{array}$ & $\begin{array}{l}\text { Chronic failure to adequately invest in, upgrade } \\
\text { and secure infrastructure networks }\end{array}$ \\
\hline & 7 & $\begin{array}{l}\text { Recurring liquidity } \\
\text { crises }\end{array}$ & $\begin{array}{l}\text { Recurring shortages of financial resources from } \\
\text { banks and capital markets }\end{array}$ \\
\hline & 8 & $\begin{array}{l}\text { Severe income } \\
\text { disparity }\end{array}$ & $\begin{array}{l}\text { Widening gaps between the richest and the } \\
\text { poorest citizens }\end{array}$ \\
\hline & 9 & $\begin{array}{l}\text { Unforeseen negative } \\
\text { consequences of } \\
\text { regulation }\end{array}$ & $\begin{array}{l}\text { Regulations that do not achieve the desired } \\
\text { effect, and instead negatively impact } \\
\text { industry structures, capital flows and market } \\
\text { competition }\end{array}$ \\
\hline & 10 & $\begin{array}{l}\text { Unmanageable } \\
\text { inflation or deflation }\end{array}$ & $\begin{array}{l}\text { Failure to redress extreme rise or fall in the } \\
\text { value of money relative to prices and wages }\end{array}$ \\
\hline
\end{tabular}




\begin{tabular}{|c|c|c|c|}
\hline $\begin{array}{l}\text { General } \\
\text { category }\end{array}$ & & Type of risk & Description \\
\hline \multirow[t]{10}{*}{ Environmental } & 1 & $\begin{array}{l}\text { Antibiotic-resistant } \\
\text { bacteria }\end{array}$ & $\begin{array}{l}\text { Growing resistance of deadly bacteria to } \\
\text { known antibiotics }\end{array}$ \\
\hline & 2 & $\begin{array}{l}\text { Failure of climate } \\
\text { change adaptation }\end{array}$ & $\begin{array}{l}\text { Governments and business fail to enforce } \\
\text { or enact effective measures to protect } \\
\text { populations and transition businesses impacted } \\
\text { by climate change }\end{array}$ \\
\hline & 3 & $\begin{array}{l}\text { Irremediable } \\
\text { pollution }\end{array}$ & $\begin{array}{l}\text { Air, water or land permanently contaminated } \\
\text { to a degree that threatens ecosystems, social } \\
\text { stability, health outcomes and economic } \\
\text { development }\end{array}$ \\
\hline & 4 & $\begin{array}{l}\text { Land and waterway } \\
\text { use mismanagement }\end{array}$ & $\begin{array}{l}\text { Deforestation, waterway diversion, mineral } \\
\text { extraction and other environment-modifying } \\
\text { projects with devastating impacts on } \\
\text { ecosystems and associated industries } \\
\end{array}$ \\
\hline & 5 & $\begin{array}{l}\text { Mismanaged } \\
\text { urbanisation }\end{array}$ & $\begin{array}{l}\text { Poorly planned cities, urban sprawl and } \\
\text { associated infrastructure that amplify drivers } \\
\text { of environmental degradation and cope } \\
\text { ineffectively with rural exodus }\end{array}$ \\
\hline & 6 & $\begin{array}{l}\text { Persistent extreme } \\
\text { weather }\end{array}$ & $\begin{array}{l}\text { Increasing damage linked to greater } \\
\text { concentration of property in risk zones, } \\
\text { urbanisation or increased frequency of extreme } \\
\text { weather events }\end{array}$ \\
\hline & 7 & $\begin{array}{l}\text { Rising greenhouse } \\
\text { gas emissions }\end{array}$ & $\begin{array}{l}\text { Governments, businesses and consumers } \\
\text { fail to reduce greenhouse gas emissions and } \\
\text { expand carbon sinks }\end{array}$ \\
\hline & 8 & $\begin{array}{l}\text { Species } \\
\text { overexploitation }\end{array}$ & $\begin{array}{l}\text { Threat of irreversible biodiversity loss through } \\
\text { species extinction or ecosystem collapse }\end{array}$ \\
\hline & 9 & $\begin{array}{l}\text { Unprecedented } \\
\text { geophysical } \\
\text { destruction }\end{array}$ & $\begin{array}{l}\text { Existing precautions and preparedness } \\
\text { measures fail in the face of geophysical } \\
\text { disasters of unparalleled magnitude such as } \\
\text { earthquakes, volcanic activity, landslides or } \\
\text { tsunamis }\end{array}$ \\
\hline & 10 & $\begin{array}{l}\text { Vulnerability to } \\
\text { geomagnetic storms }\end{array}$ & $\begin{array}{l}\text { Critical communication and navigation systems } \\
\text { disabled by effects from colossal solar flares }\end{array}$ \\
\hline \multirow[t]{6}{*}{ Geopolitical } & 1 & $\begin{array}{l}\text { Critical fragile } \\
\text { states }\end{array}$ & $\begin{array}{l}\text { A weak state of high economic importance } \\
\text { that faces strong likelihood of collapse }\end{array}$ \\
\hline & 2 & $\begin{array}{l}\text { Diffusion of } \\
\text { weapons of mass } \\
\text { destruction }\end{array}$ & $\begin{array}{l}\text { The availability of nuclear, chemical, biological } \\
\text { and radiological technologies and materials } \\
\text { leads to crises }\end{array}$ \\
\hline & 3 & $\begin{array}{l}\text { Entrenched } \\
\text { organised crime }\end{array}$ & $\begin{array}{l}\text { Highly organised and very agile global } \\
\text { networks committing criminal offences }\end{array}$ \\
\hline & 4 & $\begin{array}{l}\text { Failure of diplomatic } \\
\text { conflict resolution }\end{array}$ & $\begin{array}{l}\text { The escalation of international disputes into } \\
\text { armed conflicts }\end{array}$ \\
\hline & 5 & $\begin{array}{l}\text { Global governance } \\
\text { failure }\end{array}$ & $\begin{array}{l}\text { Weak or inadequate global institutions, } \\
\text { agreements or networks, combined with } \\
\text { competing national and political interests, } \\
\text { impede attempts to cooperate on addressing } \\
\text { global risks }\end{array}$ \\
\hline & 6 & $\begin{array}{l}\text { Militarisation of } \\
\text { space }\end{array}$ & $\begin{array}{l}\text { Targeting of commercial, civil and military } \\
\text { space assets and related ground systems that } \\
\text { can precipitate or escalate an armed conflict }\end{array}$ \\
\hline
\end{tabular}


1. Governing for the Future while Meeting the Challenges of Today

\begin{tabular}{|c|c|c|c|}
\hline \multirow{5}{*}{$\begin{array}{l}\text { General } \\
\text { category }\end{array}$} & & Type of risk & Description \\
\hline & 7 & $\begin{array}{l}\text { Pervasive } \\
\text { entrenched } \\
\text { corruption }\end{array}$ & $\begin{array}{l}\text { The widespread and deep-rooted abuse of } \\
\text { entrusted power for private gain }\end{array}$ \\
\hline & 8 & Terrorism & $\begin{array}{l}\text { Individuals or a non-state group successfully } \\
\text { inflict large-scale human or material damage }\end{array}$ \\
\hline & 9 & $\begin{array}{l}\text { Unilateral resource } \\
\text { nationalisation }\end{array}$ & $\begin{array}{l}\text { Unilateral moves by states to ban exports } \\
\text { of key commodities, stockpile reserves and } \\
\text { expropriate natural resources }\end{array}$ \\
\hline & 10 & $\begin{array}{l}\text { Widespread illicit } \\
\text { trade }\end{array}$ & $\begin{array}{l}\text { Unchecked spread of illegal trafficking of } \\
\text { goods and people throughout the global } \\
\text { economy }\end{array}$ \\
\hline \multirow[t]{10}{*}{ Societal } & 1 & $\begin{array}{l}\text { Backlash against } \\
\text { globalisation }\end{array}$ & $\begin{array}{l}\text { Resistance to further increased cross-border } \\
\text { mobility of labour, goods and capital }\end{array}$ \\
\hline & 2 & $\begin{array}{l}\text { Food shortage } \\
\text { crises }\end{array}$ & $\begin{array}{l}\text { Inadequate or unreliable access to appropriate } \\
\text { quantities and quality of food and nutrition }\end{array}$ \\
\hline & 3 & $\begin{array}{l}\text { Ineffective illicit- } \\
\text { drug policies }\end{array}$ & $\begin{array}{l}\text { Continued support for policies that do not } \\
\text { abate illegal drug use but do embolden criminal } \\
\text { organisations, stigmatise drug users and } \\
\text { exhaust public resources }\end{array}$ \\
\hline & 4 & $\begin{array}{l}\text { Mismanagement of } \\
\text { population ageing }\end{array}$ & $\begin{array}{l}\text { Failure to address both the rising costs and the } \\
\text { social challenges associated with population } \\
\text { ageing }\end{array}$ \\
\hline & 5 & $\begin{array}{l}\text { Rising rates of } \\
\text { chronic disease }\end{array}$ & $\begin{array}{l}\text { Increasing burden of illness and long-term } \\
\text { costs of treatment threaten recent societal } \\
\text { gains in life expectancy and quality }\end{array}$ \\
\hline & 6 & $\begin{array}{l}\text { Rising religious } \\
\text { fanaticism }\end{array}$ & $\begin{array}{l}\text { Uncompromising sectarian views that polarise } \\
\text { societies and exacerbate regional tensions }\end{array}$ \\
\hline & 7 & $\begin{array}{l}\text { Unmanaged } \\
\text { migration }\end{array}$ & $\begin{array}{l}\text { Mass migration driven by resource scarcity, } \\
\text { environmental degradation and lack of } \\
\text { opportunity, security or social stability }\end{array}$ \\
\hline & 8 & $\begin{array}{l}\text { Unsustainable } \\
\text { population growth }\end{array}$ & $\begin{array}{l}\text { Unsustainably low or high population growth } \\
\text { rates and sizes, creating intense and rising } \\
\text { pressure on resources, public institutions and } \\
\text { social stability }\end{array}$ \\
\hline & 9 & $\begin{array}{l}\text { Vulnerability to } \\
\text { pandemics }\end{array}$ & $\begin{array}{l}\text { Inadequate disease surveillance systems, } \\
\text { failed international coordination and the lack of } \\
\text { vaccine production capacity }\end{array}$ \\
\hline & 10 & Water supply crises & $\begin{array}{l}\text { Decline in the quality and quantity of fresh } \\
\text { water combines with increased competition } \\
\text { among resource-intensive systems, such as } \\
\text { food and energy production }\end{array}$ \\
\hline \multirow[t]{3}{*}{ Technological } & 1 & $\begin{array}{l}\text { Critical systems } \\
\text { failure }\end{array}$ & $\begin{array}{l}\text { Single-point system vulnerabilities trigger } \\
\text { cascading failures of critical information } \\
\text { infrastructure and networks }\end{array}$ \\
\hline & 2 & Cyber attacks & $\begin{array}{l}\text { State-sponsored, state-affiliated, criminal or } \\
\text { terrorist cyber attacks }\end{array}$ \\
\hline & 3 & $\begin{array}{l}\text { Failure of } \\
\text { intellectual property } \\
\text { regime }\end{array}$ & $\begin{array}{l}\text { The loss of the international intellectual } \\
\text { property regime as an effective system for } \\
\text { stimulating innovation and investment }\end{array}$ \\
\hline
\end{tabular}




\begin{tabular}{|l|l|l|l|}
\hline $\begin{array}{l}\text { General } \\
\text { category }\end{array}$ & & Type of risk & Description \\
\hline \multirow{6}{*}{} & 4 & $\begin{array}{l}\text { Massive digital } \\
\text { misinformation }\end{array}$ & $\begin{array}{l}\text { Deliberately provocative, misleading or } \\
\text { incomplete information disseminates rapidly } \\
\text { and extensively with dangerous consequences }\end{array}$ \\
\cline { 2 - 4 } & 5 & $\begin{array}{l}\text { Massive incident of } \\
\text { data fraud/theft }\end{array}$ & $\begin{array}{l}\text { Criminal or wrongful exploitation of private } \\
\text { data on an unprecedented scale }\end{array}$ \\
\cline { 2 - 4 } & 6 & $\begin{array}{l}\text { Mineral resource } \\
\text { supply vulnerability }\end{array}$ & $\begin{array}{l}\text { Growing dependence of industries on minerals } \\
\text { that are not widely sourced with long } \\
\text { extraction-to-market time lag for new sources }\end{array}$ \\
\cline { 2 - 4 } & 7 & $\begin{array}{l}\text { Proliferation of } \\
\text { orbital debris }\end{array}$ & $\begin{array}{l}\text { Rapidly accumulating debris in high-traffic } \\
\text { geocentric orbits jeopardises critical satellite } \\
\text { infrastructure }\end{array}$ \\
\cline { 2 - 4 } & 8 & $\begin{array}{l}\text { Unforeseen } \\
\text { consequences of } \\
\text { climate change } \\
\text { mitigation }\end{array}$ & $\begin{array}{l}\text { Attempts at geo-engineering or renewable } \\
\text { energy development result in new complex } \\
\text { challenges }\end{array}$ \\
\cline { 2 - 4 } & 9 & $\begin{array}{l}\text { Unforeseen } \\
\text { consequences of } \\
\text { nanotechnology }\end{array}$ & $\begin{array}{l}\text { The manipulation of matter on atomic and } \\
\text { molecular levels raises concerns about } \\
\text { nanomaterial toxicity }\end{array}$ \\
\cline { 2 - 4 } & 10 & $\begin{array}{l}\text { Unforeseen } \\
\text { consequences of } \\
\text { new life-science } \\
\text { technologies }\end{array}$ & $\begin{array}{l}\text { Advances in genetics and synthetic biology } \\
\text { produce unintended consequences, mishaps or } \\
\text { are used as weapons }\end{array}$ \\
\hline
\end{tabular}

Source: Howell, L. (ed.) 2013. Global Risks 2013, $8^{\text {th }}$ ed (Geneva: World Economic Forum).

Of these top-50 global risks, the five with the greatest likelihood (as assessed in late 2012 and early 2013 by the report's authors) were: severe income disparity; chronic fiscal imbalances; rising greenhouse gas emissions; water supply crises; and mismanagement of population ageing. The top-five risks in terms of impact were: major systemic financial failure; water supply crises; chronic fiscal imbalances; food shortage crises; and the diffusion of weapons of mass destruction. Interestingly, two risks appear in both lists: chronic fiscal imbalances and water supply crises. The emphasis placed on severe income disparity - that is, the widening gap between the richest and the poorest citizens in many states - is also intriguing. It suggests that the report's authors concluded that income inequality has reached such high levels in a sufficiently large number of states as to pose significant risks to political stability and social cohesion. Whether this assessment is correct, of course, is open to debate.

While the risk classification system adopted by Howell (2013) has merit, it is important to note that many of the 50 global risks cannot be readily confined to a single category. For instance, environmental risks, such as species overexploitation, poor water management and the development of antibioticresistant bacteria, may pose significant economic risks (or even geopolitical risks). Likewise, societal risks, such as rising religious fanaticism, may affect 
geopolitical stability, which in turn may have negative economic impacts. Moreover, many of the risks are closely interconnected. For instance, food shortage crises (listed under societal risks) are clearly linked to water supply crises, land and waterway mismanagement, persistent extreme weather and rising greenhouse gas emissions. In short, many of the 50 risks are linked in various ways and/or have multiple potential consequences for humanity.

For the purposes of this brief analysis, I have clustered the major challenges facing humanity over the coming decades into four broad categories: the pressures arising from population growth, demographic changes and migration; the environmental challenges arising from resource scarcity and the waste absorption limits of the biosphere; a range of other, largely human-induced challenges and risks; and the seemingly increased prevalence of natural disasters.

\section{Population-Based and Demographic Changes}

Looking forward over the next half-century, the global population is projected to expand - from around 7 billion in 2012 to around 9 billion by 2050, and possibly 10-12 billion by the close of the twenty-first century (Royal Society 2012). This growth is likely to exacerbate existing resource scarcities (for example, with respect to land, water and energy supplies), intensify the stresses on certain ecosystem services, increase migration pressures and generate new geopolitical tensions. The risks of food shortages and international tensions over water and energy resources are particularly concerning.

In the developed world, most countries, including Australia and New Zealand, will experience significant demographic shifts. Their populations will age and become more diverse. Migration - whether internal or external, inward or outward - may pose significant issues of adjustment, inclusion and social cohesion for national governments. These factors will also pose a range of economic (including fiscal) and political challenges. A notable migration issue over the longer term in the South Pacific region will be the inundation of certain low-lying micro-states, such as Kiribati and Tuvalu, as a result of sea-level rise, and the need to relocate entire peoples.

\section{Environmental Challenges}

Likewise, various global (and sub-global) biophysical constraints - including the scarcity of non-renewable resources (such as oil and gas) and conditionally renewable resources (such as water) - and increasing pressures on the planet's common-pool resources (for example, the atmosphere, oceans and biodiversity) will generate a range of economic and social stresses. Compounding this, climate change over the coming century is very likely to increase the frequency and/ or severity of meteorological and hydrological disasters (see IPCC 2007, 2013). Human settlements will thus face a growing threat of damaging large-scale events (for example, severe droughts, floods, heatwaves and bushfires). 
Future-Proofing the State

\section{Other Human-Induced Challenges and Risks}

Governments face many other types of difficulties (including largely self-inflicted wounds, such as the costly 'leaky-building disaster' in New Zealand or the failure of local councils to require fireproof housing in bushfire-prone areas in Australia), which need to be managed and responded to. These human-induced challenges and risks vary in their likely magnitude, impact and duration, and include

- global and regional economic shocks, such as the global financial crisis of 2008-09 and the related sovereign debt crisis of 2011

- major technological changes, with resultant impacts on the pattern and structure of employment

- civil unrest and disorder, perhaps triggered by high-profile, politically divisive events

- acts of terrorism, cyber attacks and the failure of critical systems

- entrenched inequalities in wealth, income and opportunities, including severe and persistent ethnic inequalities

- major health problems, including the rise of obesity and epidemics

- biological disasters resulting from specific bacteria or viruses (exacerbated in some agricultural subsectors by crop monocultures)

- changes in societal values, attitudes, expectations and family structures, with significant implications, amongst other things, for the delivery of various social services

- changes in the nature and pattern of social media and mass communication, with implications for democratic processes, the character of social movements and forms of protest

- the risks posed by the increasing complexity and interdependence (at various spatial levels) of multiple systems - social, technical and infrastructure.

\section{Natural Disasters}

In recent years many countries have witnessed highly destructive natural disasters, including major meteorological, hydrological and seismic events. In the case of Australia and New Zealand, these have included

- the Victorian and West Australian bushfires of 2009-11, the widespread bushfires of late 2012 and early 2013, and the NSW bushfires in October 2013

- the large-scale flooding in Queensland, New South Wales and Victoria during late 2010 and early 2011, with subsequent major flooding events during the summers of 2011-12 and 2012-13 
- the Canterbury earthquakes, especially those of September 2010, February 2011, June 2011 and December 2011

- the Cook Strait earthquakes in July and August 2013, which did significant damage in the small settlement of Seddon, but fortunately only modest damage in Wellington

- damaging hailstorms in Sydney (19 April 1999), Melbourne (7 March 2010) and Perth (22 March 2010)

- major tropical cyclones, such as Larry (2006) and Yasi (2011)

- protracted and severe drought conditions in many parts of Australia during 2003-09.

Some of these events not merely caused large-scale damage to property and infrastructure (and related economic losses), but also resulted in significant loss of life.

Equally, within the wider Asia-Pacific region, there has been a string of devastating natural disasters in recent years - most notably: severe floods in Pakistan in mid 2010 and mid 2011, and in Thailand in late 2011; and large earthquakes and tsunamis in Indonesia in late December 2004, in the South Pacific islands in late March 2009, in Chile in late February 2010 and in Japan in mid March 2011. Epidemics, such as the Severe Acute Respiratory Syndrome (SARS) pandemic in 2002-03 and the H1Nl influenza (that is, swine flu) pandemic during 2009-10, have also posed challenges for many governments in the Asia-Pacific region. Other kinds of natural disasters remain constant possibilities, including volcanic eruptions, cyclones and solar flares.

Clearly, some of these risks and challenges could be isolated events; but many may impact to varying degrees on our societies simultaneously. Indeed, there is an increased risk of multiple disasters occurring within short periods, thus placing extreme pressures on the resources and capabilities of the state (at all levels) and the communities affected. In response terms, this implies that governments and communities will have to deal with inordinately complex and interrelated problems, many taking the guise of 'wicked' problems defying simple or immediate solutions. Unfortunately, some of these disasters may be 'unmanageable' in that governments will lack either the resources to cope or the capacity to intervene with any degree of effectiveness, and local communities will be left to fend for themselves for extended periods. But it is surely better to know about, prepare and plan for such eventualities ahead of time, even if our responses may be inadequate. The fact that we cannot anticipate and regulate all risks, let alone control the future, does not mean that governments should simply relax and sit on their hands. 


\section{Preparing for Long-Term Challenges and Future Risks}

Governments, in short, will be confronted by a multiplicity of complex future risks, the scope, scale and severity of which may all increase over time-in some cases markedly. Of course, such risks will also affect many other important stakeholders, such as business, civil society organisations (for example, think tanks, research institutes, interest groups and professional bodies) and local communities. Together they will be expected to prepare for and help manage these eventualities. But such actors are not necessarily presently geared up to deal adequately with the many challenges on the horizon. And to act appropriately and effectively may require more sophisticated thinking than has hitherto been demonstrated, as well as new ways of approaching problems. In this context, some stakeholders are unlikely to have the required knowledge or research capabilities, the right staff and skills, the appropriate mindset and aptitudes, or even the authority or capacity to deal with future risks.

Moreover, given the nature, magnitude and range of the risks, many different tasks require attention. In no order of importance, these include

- the need for improved global and national governance of common-pool resources, including the capacity to take effective action to reduce long-term risks, such as human-induced climate change, resource scarcity, biodiversity loss and ocean acidification

- the need for heightened disaster preparedness and adaptive capacity

- the need for robust scientific evidence and a capacity to assess risks in a rigorous and independent manner

- the capacity to mobilise resources quickly and efficiently

- the capacity to maintain critical infrastructure, including essential services, social assistance programs and important supply chains, during protracted 'emergencies'

- the need to enhance coordination and cooperation at multiple levels: intergovernmental, inter-agency and across governmental and nongovernmental organisations, including business and the not-for-profit sector

- the need to foster increased community resilience and forms of community self-reliance

- the need for improved investment in risk mitigation, including enhancing the resilience of critical infrastructure (for example, via greater built-in redundancy). This applies to water services, wastewater services, electricity networks, transport infrastructure, telecommunications infrastructure, and other essential services. Although public funds will be available to cover 
some of the costs of such re-engineering, more creative funding instruments will also be needed, including shared funding, co-funding, public-private partnerships, levies and charging.

Governments do not, of course, 'own' this policy space; nor will they necessarily deal with future challenges solely by means of direct or in-house provision. It is a shared space and requires a shared commitment across all relevant stakeholders. It will also entail smarter policy responses, cultural changes, some normative reconceptualisation, and learning from empirical experiences of what works (whether locally or elsewhere).

The challenges and risks outlined above raise a variety of philosophical and practical questions. One of these concerns the respective roles and responsibilities of governments, business, civil society organisations, communities and individuals, including how risks should be shared and how the 'policy bounds' or ambits should be negotiated. But there are many related questions.

- To what extent can (and should) the state reduce the range and magnitude of the risks it is likely to face over the coming decades, and how should it prepare to manage the hazards, disasters and exogenous shocks (whether natural or human induced) that are bound to occur and over which governments have little or no control?

- Of the risks that societies face, which are the primary responsibility of governments, and how, in general, should the costs be shared and/or allocated?

- What weight should be placed on the precautionary principle, and what potential benefits and opportunities might we be willing to sacrifice in the interests of 'playing safe'?

- To what extent can (and should) the state enhance its resilience (for example, by increasing reserves and redundancy) and hence its capacity to withstand negative shocks, whether economic, social, ecological, geological or meteorological?

- What policy frameworks and approaches appear to offer governments the best prospects of coping with uncertainty, minimising the impacts of negative shocks and maximising the potential to seize new opportunities?

- How can governments, other stakeholders and communities best learn from their mistakes, avoid repeating the failures of the past, and minimise policy regress over time as the political salience of a major disaster recedes? 


\section{Future-Proofing the State}

In broad terms, the notion of 'future-proofing' refers to the process of attempting to anticipate or predict future developments in order to: a) prevent, or at least mitigate, possible negative consequences by reducing vulnerability and enhancing resilience; and b) seize opportunities as and when they arise. It has been applied to various spheres of human activity including, for instance, the future-proofing of electronic data - where it means selecting data formats and physical media that will maximise the chances of enabling continued access to the original information.

Accordingly, future-proofing entails exercising foresight and implementing strategies that are likely to enhance sustainability and resilience (for example, institutional, fiscal, environmental, innovation, incentives, social capital and so on) and reduce potential hazards and threats. From the state's perspective, governments can influence, at least modestly or at the margins, the kind of futures that societies experience. At the same time, however, human societies and the natural world are dynamic. The extent to which any future-proofing can be effective will necessarily be limited, as underscored by Bridget Hutter in Chapter 9: there are many uncertainties; our predictive capacity is constrained; some risks cannot be foreseen and/or are difficult to assess; some risks are costly and/or politically inconvenient to mitigate; and other risks may be very difficult, if not impossible, to mitigate (for example, because they are globally driven or beyond the control of governments to influence).

Many areas of academic research are relevant to the issues surrounding 'futureproofing', including future studies, governance (including adaptive and lateral governance), strategic management, organisational learning, sustainability, social capital, complexity, transformational change, innovation, and so forth. There is also a vast body of work on risk identification, risk assessment and management, distinguishing between risks and uncertainty, risk sharing and financing, asymmetries of information, and how to realign incentives and avoid moral hazards.

The remainder of this chapter considers briefly five particular challenges that are crucial if progress is to be made towards the goal of future-proofing the state. Many of these are explored more fully in subsequent chapters

1. increasing the incentives for governments to consider important long-term policy issues

2. increasing the resilience of public institutions and critical subsystems and hence their capacity to cope with future shocks

3. maintaining and enhancing trust in public institutions 
4. improving emergency management and disaster recovery

5. improving the capacity of governments to learn from their own failures.

\section{Bringing Important Long-Term Issues into Short-Term Political Focus}

A significant body of social science literature suggests that democracies are systematically biased towards the present. In short, it is argued that elected governments tend to focus on short-term issues at the expense of long-term issues, and typically give more weight to the interests of current voters over those of future generations. This 'presentist bias' or 'political myopia' is evident in many policy domains across the democratic world. Examples include underinvestment in major infrastructure, inadequate protection of biodiversity, an unwillingness to address the long-term fiscal costs of current policy settings (for example, with respect to retirement income policy, longterm welfare dependency, student finance and criminal justice policy), the poor management of natural capital (especially critical, non-substitutable resources), and inadequate measures to mitigate human-induced climate change. The longterm economic, fiscal, social and environmental consequences of such political myopia are potentially serious, both in scope and in scale.

In relation to possible solutions, it is important to consider the merits (or otherwise) of various institutional arrangements and policy measures that governments have already put in place in an endeavour to give more weight to the interests of future generations and/or ensure that policymakers take future risks (and opportunities) more seriously. Such arrangements include

- $\quad$ statutory requirements for treasuries/finance ministries to produce periodic long-term fiscal forecasts and statements of the long-term fiscal position of the government (for example, in New Zealand the Treasury is required to produce annual 10-year fiscal forecasts and periodic 40-year forecasts)

- statutory requirements for government departments/agencies to prepare and publish strategic plans or related documents that scan the horizon, identifying risks and developing possible policy responses

- statutory requirements for local governments to undertake long-term planning and disaster management exercises on a regular basis

- the creation within relevant agencies of specialist risk-management and contingency planning units

- the establishment of independent institutions with specific mandates to consider long-term policy issues (for example, commissions for the future, planning councils, and so on) 
- enhanced legislative oversight with respect to long-term policy issues (for example, Finland's Parliament has a Committee for the Future, which, among other things, undertakes research on futures-related issues)

- legislative provisions that require policymakers at various levels of government to take account of the precautionary principle in their decisionmaking processes

- constitutional requirements for policymakers to consider the interests of future generations (for example, as noted by Pierre-Alain Schieb in Chapter 3, Finnish prime ministers are required on taking office to outline in Parliament their vision for Finland 15 years ahead).

The relative merits of these and other policy instruments designed to bring long-term issues and considerations into short-term political focus need careful consideration.

\section{Building Resilience to Cope with Future Stresses and Shocks}

As previously highlighted, resilience is critical to the successful management and regulation of risks. In recent years the notion of resilience has been much in vogue and has generated a large literature, especially in relation to socioecological resilience. Many definitions and conceptualisations are on offer. As applied in engineering, for example, resilience has been associated with three main properties: the capacity to bounce back after a shock or stress; the capacity to endure greater stresses; and the capacity to be disturbed less by a given level of stress (Howell 2013:37). But while this particular understanding of resilience is relevant to objects or infrastructure, such as buildings, bridges and dams, it is less appropriate to people, institutions and systems. For instance, an institution or a system may demonstrate resilience 'not by returning exactly to its previous state, but instead by finding different ways to carry out essential functions; that is, by adapting' (Howell 2013:37). Accordingly, a broader understanding of resilience is required. In this regard, the Intergovernmental Panel on Climate Change (IPCC 2007:90) has defined the resilience of a social or ecological system as its ability 'to absorb disturbances while retaining the same basic structure and ways of functioning, the capacity for self-organization, and the capacity to adapt to stress and change'. A resilient system, therefore, is one that can maintain its basic functions when confronted with disturbances or stresses; it retains, as Jocelyne Bourgon argues in Chapter 4, the 'capacity to adapt, to evolve and to prosper in a turbulent world'.

Resilience is closely related to the notion of vulnerability, as Brian Walker notes in Chapter 11. Vulnerability refers to a community's or a system's susceptibility to, and ability (or lack thereof) to cope with, adverse impacts. The degree of vulnerability depends on the nature, magnitude and duration of the shocks that 
are experienced, the sensitivity of the community or system to these shocks, and their capacity to adapt. While some known risks can be reduced or even eliminated, other risks are either too costly or too difficult to reduce. Having the capacity to manage 'residual risk', as it is termed, is critical.

Building on such insights, at least three kinds of capabilities are essential if a country, and in particular its governmental institutions, is to be resilient: a) adaptability - able to respond and adapt to changing demands and circumstances; b) sturdiness or robustness - able to survive unexpected or sudden shocks, including systemic shocks; and c) resourcefulness and recoverability - able to re-establish a 'desired equilibrium' (whether this is close to the previous order of things or a new regime of some kind) while ensuring critical services and operations are maintained. If these capabilities are important at the national or governmental level, they are equally necessary at the sub-national, subsystem and sectoral levels. Indeed, the resilience of governmental institutions will be influenced by, and dependent upon, the capacity of the various subsystems to cope with the stresses to which they are subjected.

Such an analysis immediately raises two questions. First, how might the resilience of countries (and their respective subsystems) best be assessed? And second, how can the level of resilience be improved and, moreover, improved in the most cost-effective manner?

With regard to an assessment diagnostic, Howell (2013) proposes a framework for evaluating a nation's resilience involving five subsystems (economic, environmental, governance, infrastructure and social) and five components of resilience (robustness, redundancy, resourcefulness, response and recovery). For each of the five components, specific evaluative criteria or attributes are identified. For instance, 'robustness' is defined as 'the ability to absorb and withstand disturbances and crises' (Howell 2013:38). Ways of increasing robustness might include ensuring that there are adequate fail-safes and firewalls in a country's critical networks and infrastructure. Criteria for assessment might include specific tests of reliability, the capacity to contain the impact of unexpected shocks and the adaptive capacity of decision-making processesor to take another example: redundancy. The concept of redundancy refers to 'having excess capacity and back-up systems' to help ensure core functions and critical systems can be maintained in the event of unexpected shocks, disturbances and volatility (Howell 2013:39). Without doubt, redundancy can be vital, as both Peter Ho and David Kirk emphasise in their contributions to this volume. Criteria for assessing whether the level of redundancy is adequate might include the capacity of backup systems to undertake a specified level of core functions and the extent to which risks are spread through the provision of diverse delivery systems.

It is one thing to develop a diagnostic tool to assess the level of resilience; it is quite another to apply this tool effectively and improve the level of resilience. 
Increasing the degree of redundancy will almost certainly entail additional costs. In other cases, the level of resilience may not be readily amenable to policy interventions. For instance, having a robust level of social capital-including a strong network of civil society organisations, high levels of trust and social cohesion, and a tradition of social entrepreneurship - is undoubtedly important during the response and recovery phases of major disasters (as highlighted by recent natural disasters in Australia and New Zealand and emphasised by various contributors to this volume). But it is by no means self-evident how governments can enhance the level of social capital, let alone ensure that it is properly harnessed and deployed when disaster strikes. Having said this, governments can certainly facilitate or hinder the development of social capital. For instance, empowering local communities, implementing collaborative modes of governance (and lateral governance) and co-funding various local initiatives can help facilitate, but not guarantee, the accumulation of social capital.

\section{Maintaining and Enhancing Trust in Public Institutions}

There has been considerable concern in recent decades about the decline in the level of trust in public institutions in many long-established democracies. Various explanations for the loss of trust have been advanced, but whatever the causes, there is general agreement that low trust is politically, socially and economically damaging. Other things being equal, governments are likely to be less resilient and less able to cope with difficult challenges if citizens have little trust and confidence in those who hold public office and/or provide public services. Hence, rebuilding and maintaining adequate levels of trust in public institutions should be priorities. Possible ways of addressing the current 'trust deficits' are usefully explored by Murray Petrie in Chapter 8. As he indicates, transparency, participation and robust accountability mechanisms are critical.

\section{Managing Natural Disasters: Recovery strategies, modalities, institutions and lessons}

A considerable part of this volume is devoted to the topic of natural disasters, with various reflections on the multiple challenges and opportunities such events generate for governments. This includes the ways in which governments can best prepare for, respond to and help the recovery process after disasters; the opportunities disasters provide for policy innovation and experimentation by governmental agencies (and non-governmental organisations); the role of social capital in enabling communities to cope with and recover from disasters; and the challenges large-scale disasters can pose for the maintenance of decentralised governance systems and the integrity of the democratic process.

Different kinds of disasters, of course, require different responses and modes of recovery. Localised, one-off events, such as fires or hailstorms, specific acts 
of terrorism or short-lived riots, pose different recovery challenges to largescale and protracted events, such as major floods, damaging earthquakes with numerous significant aftershocks, or substantial economic shocks, such as the Global Financial Crisis and the related sovereign debt crisis, particularly in Europe.

For good reasons, the 2012 ANZSOG conference gave particular attention to several of the major natural disasters that have afflicted Australia and New Zealand in recent years, in particular

- the Victorian bushfires in early February 2009

- the Queensland floods during late 2010 - early 2011

- the Canterbury earthquakes, especially those in September 2010 and February 2011.

In each case, these disasters caused substantial damage and generated significant stresses for the governments of the respective jurisdictions. Unsurprisingly, too, in each case the relevant governments established independent bodies to investigate aspects of each disaster and how well the response and recovery strategies worked in practice, although analysis of the latter has varied significantly, reflecting the particular circumstances and distinctive features of the disasters in question. Drawing on the reports of these independent bodies, Rachel Brookie and James Smart in their respective chapters outline and assess the recovery strategies adopted and highlight the lessons arising. Likewise, John Ombler and Sally Washington in Chapter 21 explore the opportunities created by the Canterbury earthquakes for policy innovation and, in particular, new ways of delivering public services, while in Chapter 22 Lyn Provost and her colleagues provide an audit perspective on the public sector's response to the earthquakes. Here, I briefly summarise some of the key features of the three particular disasters.

\section{The Victorian Bushfires}

The Victorian bushfires in late January and early February 2009 affected almost 80 townships, destroyed more than 2000 homes (and 3500 structures) and displaced about 7500 people; 173 people died, with more than 400 injured; there were also large forestry, agricultural and horticultural losses, with total costs estimated at more than A $\$ 4.4$ billion. The Federal and Victorian governments established the Victorian Bushfire Reconstruction and Recovery Authority (as a joint initiative) several days after the main disaster on 7 February (Black Saturday). This was headed by Christine Nixon, the outgoing commissioner of Victoria Police. Its mandate was to oversee the rebuilding of the many communities affected by the fires. Subsequently, in April 2009, the Victorian Government established a royal commission, which was asked to examine the 'causes and circumstances of the bushfires', all aspects of the government's bushfire strategy and 
responses, and the issues arising (for example, with respect to preparation and planning for future bushfire threats, land-use planning and management, the fireproofing of buildings, emergency response, the quality and availability of public information, training and resourcing, and so on). The royal commission delivered its interim report on 17 August 2009 and its final report on 31 July 2010 (which contained 67 recommendations covering a diverse range of issues, including emergency and incident management, planning and building, land management, and so on).

\section{The Queensland Floods}

Large-scale flooding affected much of Queensland (and several other States) during December 2010 and early 2011 as a result of a series of storms and cyclones. At one point, three-quarters of the State of Queensland was declared a disaster zone. The floods forced the evacuation of many thousands of people; more than 30 people lost their lives; and there was significant and protracted disruption to business activity across much of the State. Insurance losses exceeded A $\$ 1$ billion, and total economic losses may have exceeded $\mathrm{A} \$ 10$ billion (with some estimates as high as A $\$ 20-30$ billion). A recovery taskforce, headed by Major General Michael Slater, was established to coordinate initial recovery efforts. Later the Queensland Reconstruction Authority was created (under legislation) to develop, coordinate, implement and manage the Statewide plan for rebuilding and reconnecting communities affected by the floods and cyclones. The authority's board is chaired by Major General Dick Wilson, and the chief executive is Graeme Newton, previously the State's CoordinatorGeneral and Director-General of the Department of Infrastructure and Planning. The Queensland Government also established a commission of inquiry into the floods on 17 January 2011, with broad terms of reference, and the commission completed its interim report on 1 August 2011, with 175 recommendations. The Australian Government imposed a flood levy to fund reconstruction work.

\section{The Canterbury Earthquakes}

Earthquakes are very common in New Zealand, but few cause major damage. An unexpectedly large quake occurred in the vicinity of Christchurch on 4 September 2010; this was followed by three significant aftershocks - on 22 February 2011, 13 June 2011 and 23 December 2011-with numerous smaller aftershocks. The February quake resulted in the collapse of many buildings with the loss of 185 lives. The cumulative damage has thus far been substantial, with much of the central and eastern parts of the city severely affected. More than 30000 houses are estimated to have sustained damage exceeding NZ\$100 000, with the total fiscal costs estimated to exceed NZ\$13 billion and insurance losses well in excess of NZ\$20 billion.

In response to the quake in September 2010, the Government established the 
Response and Recovery Act, which was enacted on 14 September. The commission's role was to offer advice on prioritising resources and allocating funding and to help coordinate the efforts of central and local governments. Subsequently, following the February quake, the Government established the Canterbury Earthquake Recovery Authority (CERA) (also via legislation). CERA's mandate is to lead and coordinate the recovery effort, including business recovery, restoring local communities, and enabling effective and timely rebuilding. The Chief Executive of CERA is Roger Sutton. On 14 March 2011, the Government announced the establishment of the Canterbury Earthquakes Royal Commission to investigate a range of issues including building collapses and the consequent loss of life, damage to key buildings, and the adequacy of building standards and codes. An interim report was released in mid October 2011, and a final report (in seven volumes) was completed in stages during 2012. A separate technical investigation into a number of specific building collapses was commenced on 16 March 2011 by the Department of Building and Housing, and several reports have been released.

With these three major natural disasters in mind, it is important to step back and reflect on some of the broader policy issues to which they give rise. For instance, relevant questions include

- the merits or otherwise of the specific institutional arrangements that were established to investigate the disasters and coordinate the recovery process - including their design features, powers, capability, resourcing, administrative arrangements and consultative processes

- whether there was adequate leadership and competent governance, including effective intergovernmental and inter-agency coordination

- whether government agencies effectively coordinated and partnered with business, other non-governmental organisations and local communities

- whether there was adequate protection of democratic rights, including opportunities for citizen participation and consultation

- whether short-term political imperatives, such as the pressure for quick decisions on future land-use options, prevailed over long-term planning considerations and the wider public interest

- whether policymakers applied the lessons arising from previous disasters, both local and international (for example, Kobe and New Orleans), in their disaster response and recovery processes.

Quite apart from this, the large-scale disasters that have afflicted Australia and New Zealand in recent years have raised a raft of difficult policy issues that will no doubt be the subject of ongoing and vigorous debate. Such issues include: the cost of, and limits to, insurance (and reinsurance); the related question of how the losses arising from major disasters should be shared across the relevant communities (including taxpayers and ratepayers); the extent to which those faced with losing their land and/or various property rights (for example, due to 
damage, flood risk, fire risk, and so on) should be compensated; and the extent to which new, and potentially costly, building standards and planning procedures should be implemented and, if so, over what time frame. Such issues, needless to say, are all politically charged and require adroit management.

\section{Responding to Human-Induced Disasters and Government Failure}

Aside from natural disasters, governments are also confronted from time to time with human-induced disasters; this includes self-inflicted wounds or government failures. Such failures are inevitable. The many possible causes include poorly designed and/or badly implemented regulatory frameworks, weak governance, human error, poor conflict management and corrupt practices. Some of these failures have been, and will no doubt continue to be, extremely costly. In New Zealand, as discussed by Peter Mumford in Chapter 7, significant changes were made to the regulation of the building industry during the 1990s, with a move from relatively prescriptive building codes to performance-based regulation. Some years later it became apparent that many new residential and commercial buildings were leaking. Investigations revealed that this was due to poor construction, the use of inappropriate materials and bad design. In short, the new performance-based regulatory framework had failed (Mumford 2011). The cost of rectifying the so-called 'leaky building' problem has been estimated at more than NZ\$10 billion.

A central issue arising from cases of this nature is whether governments are prepared to invest adequately in policy learning-including rigorous, independent evaluations of what went wrong and why, and careful analyses of how similar self-inflicted wounds might be avoided, or at least minimised, in the future. If policy learning is not an integral part of the decision-making process then it is inevitable that similar costly failures will be repeated. Thankfully, the democratic process includes some automatic stabilisers: electors ultimately reject those who prefer not to learn.

\section{Conclusion}

In summary, governments face a daunting array of risks. For various reasons, as discussed earlier, both the complexity and the magnitude of these risks appear to be increasing. Moreover, unless the crucial environmental and resource-related challenges currently confronting the global community are effectively tackled, there will be a greater likelihood of major natural disasters (for example, arising from climate change) and heightened geopolitical tensions (for example, arising from resource constraints). The existing weakness of our global governance arrangements, especially for managing common-property resources, increases 
the probability that the required policy changes will not be made- or at least will not be made in time. Accordingly, the management of, and recovery from, disasters is likely to become an ever more demanding burden on governments, both national and sub-national.

Elected officials will have little choice but to respond. Citizens, after all, expect governments to manage and, if possible, mitigate severe and large-scale risks on their behalf. Indeed, this responsibility is arguably one of the state's defining or inherent functions. But it is no easy task. Nevertheless, while governments certainly cannot control the future and while the state can only be 'futureproofed' to a modest degree, there is a strong ethical imperative for governments to devote resources to addressing long-term policy challenges and enhancing the capacity of public institutions to withstand future shocks.

Politically, perhaps the most difficult challenge is the powerful electoral incentive for decision-makers to focus on today's problems at the expense of tomorrow's threats and hazards. As discussed in this chapter, there are various institutional mechanisms that can help rebalance the incentive structure in democracies so that governments give more attention to long-term risks and the interests of future generations. But realistically such mechanisms are likely to have only a modest impact.

Finally, resilient governments depend on resilient societies; the two are inextricably intertwined. Hence, future-proofing the state requires vigorous non-governmental institutions and secure reserves of social capital. If governments have only a limited capacity to ensure such outcomes, neither are they powerless. Above all, they need to use their resources prudently and intelligently.

\section{References}

Birkland, T. 2006. Lessons of Disaster: Policy Change after Catastrophic Events (Washington, DC: Georgetown University Press).

Birkland, T. 2007. After Disaster: Agenda Setting, Public Policy and Focusing Events (Washington, DC: Georgetown University Press).

Bourgon, J. 2009. New Governance and Public Administration: Towards a Dynamic Synthesis, Canberra, 24 February.

Bourgon, J. 2011. A New Synthesis of Public Administration: Serving in the 21st Century (Montreal: McGill-Queens University Press).

Council of Australian Governments (COAG). 2011. National Strategy for Disaster Resilience, February (Canberra: COAG). 
Future-Proofing the State

Daniels, R., Kettl, D. and Kunreuther, H. (eds) 2006. On Risk and Disaster: Lessons from Hurricane Katrina (Philadelphia: University of Pennsylvania Press).

Gill, D., Pride, S., Gilbert, H., Norman, R. and Mladenovic, A. 2011. 'The Future State Project: Meeting the Challenges of the Twenty-first Century' in Bill Ryan and Derek Gill (eds), Future State: Directions for Public Management Reform in New Zealand (Wellington: Victoria University Press).

Handmer, J. and Dovers, S. 2007. Handbook of Disaster and Emergency Policies and Institutions (London: Earthscan).

Howell, L. (ed.) 2013. Global Risks 2013, Eighth edn (Geneva: World Economic Forum).

Hughes, P. and Smart, J. 2012. "You Say You Want a Revolution" ... The Next Stage of Public Sector Reform in New Zealand', Policy Quarterly, 8(1).

Intergovernmental Panel on Climate Change (IPCC). 2007. Climate Change 2007: Impacts, Adaptation and Vulnerability. Working Group II Contribution to the Fourth Assessment Report, Summary for Policy Makers and Technical Summary (Geneva: IPCC).

Intergovernmental Panel on Climate Change (IPCC). 2013. Summary for Policymakers. Working Group I Contribution to the Fifth Assessment Report (Geneva: IPCC).

Kumar, C. and Srivastava, D. 2006. Tsunami and Disaster Management: Law and Governance (Hong Kong: Sweet \& Maxwell Asia).

Lee, B., Preston, F., Kooroshy, J., Bailey, R. and Lahn, G. 2012. Resources Futures: A Chatham House Report, December (London: Chatham House).

MacHale, D. 2002. Wisdom (London: Prion Books).

May, P. and Williams, W. 1986. Disaster Policy Implementation: Managing Programs under Shared Governance (New York: Plenum Press).

Mumford, P. 2011. Enhancing Performance-Based Regulation: Lessons from New Zealand's Building Control System (Wellington: Institute of Policy Studies).

Organisation for Economic Cooperation and Development (OECD). 2012. OECD Environmental Outlook to 2050 (Paris: OECD).

Queensland Floods Commission of Inquiry. 2011. Interim Report, August (Brisbane: Queensland Floods Commission of Inquiry).

Queensland Reconstruction Authority. 2011. Operation Queenslander: The State Community, Economic and Environmental Recovery and Reconstruction Plan 2011-13 (Brisbane: Queensland Reconstruction Authority). 
Ronan, K. and Johnston, D. 2005. Promoting Community Resilience in Disasters: The Role for Schools, Youth and Families (New York: Springer).

Ryan, B. and Gill, D. (eds) 2011. Future State: Directions for Public Management in New Zealand (Wellington: Victoria University Press).

Royal Society. 2012. People and the Planet, The Royal Society Science Policy Centre Report 01/12 (London: The Royal Society).

Smil, V. 2006. Global Catastrophes and Trends - The Next Fifty Years (Boston: MIT Press).

Upton, S. 2012. Long term fiscal risks-New Zealand's case in the context of OECD countries, Paper prepared for Affording the Future Conference, Wellington.

2009 Victorian Bushfires Royal Commission. 2010. Final Report: Summary (Melbourne: State Government of Victoria). 
This text taken from Future-Proofing the State: Managing Risks, Responding to Crises and Building Resilience, edited by Jonathan Boston, John Wanna, Vic Lipski and Justin Pritchard, published May 2014 by ANU Press, The Australian National University, Canberra, Australia. 